\title{
The portrayal of gender difference toward swear word: an investigation of words and expressions used by Indonesian students
}

\author{
Siti Aisyah ${ }^{1}$, Chairuddin $^{2}$, Tera Athena ${ }^{3}$ \\ 1,2,3English Education Department, STKIP PGRI Bangkalan, Indonesia \\ ${ }^{1}$ sitiaisyahicadu@gmail.com, ${ }^{2}$ chairuddin@stkippgri-bkl.ac.id, 3teraathena@stkippgri-bkl.ac.id \\ *) correspondence: chairuddin@stkippgri-bkl.ac.id
}

\begin{abstract}
The society in using language is susceptible to any type of word including the expression of swear word. This research aims to determine of the types in swear word use based on the gender of its use in communication. Descriptive qualitative is used as a research approach and its application uses phenomenology methods. The data are from male and female students by matching them to Wardhaugh's and Jay's list of swear word. Students of elefth social three are selected for this research. Analysis of the results of gender-based reviews shows that men are stronger in the use of swear word forms. In contrast to women who are more aggressive and talk much only in their groups. Sex, death, excretion, bodily functions, religious matters, politics, mother-in-law, animals, nicknames are more widely used by men. For the types of rude comments women use more. This is indicated by their words and expressions that are more feminine and long-winded. Finally, the swear word which is included in this taboo word is used sometimes not the same for men and women.
\end{abstract}

Keywords: swear word; word choice; gender; students

\section{INTRODUCTION}

Gender is differentiating between male and female. Meyerhoff (2006: 202) argues that gender is a cultural variation between men and women which in biologically determined characteristics indicate that gender is interpreted as "sex". In interacting with each other they need a language. Gender uses language as a communication tool in society to interact with other people. Holmes (2008) says that naturally men and women are different. The form of language used by men and women is contrast. Especially in the use of language that contains swear words in the scope of the community. Swear word are usually inserted into students' communication when interacting. The use of language in a society called sociolinguistics is needed to communicate well. People's attitudes towards language and user use, language changes, and language plans. Hudson (2018) simply stated that socio- linguistics is a part of language studies in relation to society. Every word in language use is pragmatics. Yule (2010) assume that pragmatics is a communication in understanding about recognizing the meaning of words in speech and know what speakers mean by what they say and how the use of language. The language use in the society there are language variaton of language is created by the users (society). In Spolsky's view (2003) language variety is a third set of variations concerning the special variety (register) which is marked by a special vocabulary (technical terminology) associated with a profession or occupation or other defined social group and forming part of its jargon or in group variety. Based on the social context the language can produce many words used in communication. The language can be socially conditioned like children who take the words or languages from native speakers and use them with different language variations. Therefore, the use of language is a classification of language variations social.

As explained if the language is distinguished between male and female, a clear difference occurs in the vocabulary that pays attention politeness. Yule (2010) state that politeness is identical to being wise, humble and kind to others. In linguistic politeness, the most relevant concept is "face". Face is a person's self-image in public. This includes emotional and social feelings from everyone. By definition the politeness shows the awareness and consideration of other people's faces. There are 
positive and negative face a part of facial expressions. Positive face will show a solidarity and attract attention to achieve the common goal (i.e. let's cooperate for....). Negative face is liberation from coercion and pressure that is appropriate to one's own need to be connected and interwoven well when interacting in a group or community. Negative faces will show an emphasis that forces (i.e. I know you can't be bothered, but....). In use there are many types of words in the language, especially in swear words which are part of taboo words, most of them used to swear but not all taboo words are swearing words (Aji, 2014). Further, Popusoi (2018: 133) state that the swear words is a mechanism that does not necessarily mean an anger. The swear word not only verbal expressions can also be a way to overcome anger. The role of thinning info in uncovering anger combined with expressions to better understand user behavior in possible situations is frustrating. Swear word is negatively correlated with agreement, accuracy, religiosity, and sexual anxiety. Unique human facilities for swearing evolve and continue because swear words can communicate emotional information (anger, frustration) easier than non-swearwords, allowing speakers to achieve a variety of personal and social goals. There are types of swearing based on Wardhaugh's list (2006) and taboo words Jay's list (2009), it covers:

1. Sex: this term is refers to sexual activity. These sex-related SW are usually used by adults who understand the meaning of sex, (fuck, blow job, menta jata, jancok, and etc...)

2. Death: this term is refers to do something that makes others afraid. This SW is related to a thing in the form of a threat, (go to hell, mateyah, mati saja kamu, and etc...)

3. Excretion: this term is related to excretory of human to express an insult and disturbance. This form of SW this used to give a term and mention for things that you dislike, (damn, shit, brengsek, bangsat, korang ajar, and etc...)

4. Bodily functions: this term is refers to human sex organ. Usually this word is used in matters relating to intimate devices on the human body, (nipples, penis, cetakkeh, matanah, seenak jidat, tongkeng, and etc...)

5. Religious matters: this term is related with god or religion. This word can be used as a curse word because it contains a mystical element, (devil, gosh, jerengkong, setan, and etc...)

6. Politics: this term refers to the comforter. A person who high position can easily to demean others under him, (black campaign, dasar koruptor, tokang korupsi, and etc...)

7. Mother-in-law: this term is refers to insult. Mocking and making fun of older people, (motherfucker, tua bangka, and etc...)

8. Animals: this term is dealing with animals and animal behavior. Usually animals that like to attact and have cold blood, (dog, pick, crocodile, wolf in sheep's clothing, moseng, patek, cerek, monyet, and etc...)

9. Left hand: this term is refers to indicating (middle finger). This is SW by giving sign language

10. Nickname: this term is refers to familarity in a community (cong, teh, mad, and etc...)

11.Rude Comment: this term refers to expressions incompatibility or dislike for the intended person (nyenget, alay, mokong, and etc...)

Based on the types of swear word above shown an example of word of its use. From these uses there are reasons of swearing. Jay (2009: 155) have shown that depends on the main purpose of the speaker. Pronunciation the swear words signifies a number of emotions such as excitement, anger, frustration, and surprise. Control of oaths is in spontaneous forms such as the example of nickname and habits of epithets, where we seem to have little control, to form reflective meaning new obscene joke from Lacker's argument in Jay, that taboo words can be used to achieve a variety of personal and interpersonal results that may be negative and in significant in terms of impact on others, although some might argue that all use of swear words is dangerous. In some phenomena there are differences in the language of men and women in their use. Women tend to speak more than men,

Wahyuningsih (2018) states that this is due to the character possessed by women more polite and expressive. This shows that women use more words and movements that use their feelings and thoughts based on psychological and sensitive emotional states. Unlike men when using language, especially in the use of swear words, in their speech they are more directed and to the point. 
Previous study: in this research, the researcher relates the research with previous studies which are dealing with swear word used by Indonesian students. "Four Brothers" Movie was the first previous study compiled by Bangun Purwa Aji in 2014. This source was obtained from a thesis made by Faculty of Letters and Humanities State Islamic University UIN Sunan Ampel Surabaya as a final project. This study uses a descriptive qualitative method. The results of this study are the swear words which often appears in four brother films. There are seven types of swear words that are found in the Four Brother movie.

The second previous study is "Why Are Males Inclined to Use Strong Swear Words more than Females? An Evolutionary Explanation Based on Male Intergroup Aggressiveness". This research was taken from Journal of Elsevier and uploaded in 2015, created by Emre Guvendir. This study shows that the use of swear words men are more aggressive than women because male do not have the potential to control emotions that increase.

Moreover, a thesis created by Nurhayati in

2007 entitled "The Use of Swear Words and its Relationship with Taboo Words in Crank". Conclusions from the results of the study show that based on the analysis that has been made made results that swear words are used by people to express emotions. Swear words used by characters are very strong. In the results of the analysis the character has expressed it in a state of irritation, surprise, indifference, insult, and rejection.

The last previous study is "Men and Women Differences in Using Language: A Case Study of Students at STAIN Kudus". This research was taken from Journal of English Education, Literature, and Culture (EduLite) and uploaded in 2018, created by Sri Wahyuningsih. This study shows that the use of swear words male are more directive and tend to use simple words whereas the female who are expressive. So, in talking women are wordy. They show differences in using language and this study uses a descriptive qualitative method. The results of this study that male and female students show differences in their forms, contents, and uses.

\section{METHODS}

In conducting this research, researchers used a qualitative descriptive research approach and phenomenological method as its application. Therefore, researchers focus more on text analysis obtained from observations in the form of field notes. The objects of this study were students based on sex in class XI IPS3 as the target of SMAN 4 Bangkalan. The data of this study were described and analyzed in the form of tables based on the type of swear words used by students based on gender. There were fifteen male students and ten female students in class XI IPS3. In this study, researchers were the main research instruments to analyze field notes in the form of student conversations. Researchers collected the data through several instruments, which include: observation and field notes, question- naires, interviews, and recording data. Next, the data were analyzed using a number of steps: the first is recording students' conversations and giving field notes while paying attention to what they are saying. Second, the researchers distributed question- naires to be filled out by students based on their experiences while using swear words. Third, researchers conducted interviews with high school students in Madura as objects. After that, researchers also took documentation as evidence from the research.

\section{RESULTS AND DISCUSSION}

There are two results from the research in this section to be discussed; the first, the type of swear words based on gender. This is done to find out whether students' conversations based on gender are in the type of using swear words. Secondly, how to use swear words in students' conversations based on gender. This is done to find out the use of swear words of students based on gender in their conversations. The analysis material that the researchers observed was taken from the conversation of twenty students of class XI IPS3 at SMAN 4 Bangkalan. To find out more in detail about both, here the results of the relevance analysis will be discussed below: 
Aisyah, S., Chairuddin, Athena, T.

Result: Some Types of the Swear Word Based on the Gender Used by Students at SMAN 4 Bangkalan Madura

The use of swear words based on gender used by students of SMAN 4 Bangkalan class XI IPS3.

The researcher pay attention to the words and expressions they use. Found data that matched Wardhaugh's list of swear words and Jay's taboo list of words classified by type of swear word. From the data taken from the distribution of questionnaires filled out and observation by researcher for students based on their experience shows a difference. Based on the results of the questionnaire classification there were nine male and five female students who had said the type of the word sex as a taboo word that led to the swear word:

\section{Male user}

Sample 1

Musleh: jancok

Female user

Sample 2

Findy: nak kanak reh mokong kabbhi jancok ngara jeh

Likewise, later in the type of death there are fourteen men and seven women in the use of the word.

\section{Male users}

Sample 3

Adit: ye cong bangsat cok (while telling his chronology to his friends)

Sample 4

Female user

Devina: coonnggg coonngg mek cellep jiah deng hedeh cong. Cek bengkesseh hedeh coonnggg For excretion fourteen male and six female students have used this type of word.

\section{Male user}

\section{Sample 5}

Irfan: pola ken mateyah

Devina: ya Allah

The results of observation do not show any female says about the type of excretion in bodily functions fourteen men and seven women use this type of word.

\section{Male user}

Sample 6

Fery: cetakkeh yeh. Pesse cong

\section{Sampel 7}

\section{Female user}

Devina: (call the fery with a nickname) Fery gedeng cetak a merecep

The type of religious matters consists of fourteen men and eight women who use this swear word.

Sample 8

Male user

Feri: lel setan lok geradduh

Sample 9

Female user

Devina: ella Lely le keluar setannah le keluar 
In the type of politics that seven men and three women who used it. While the observations do not show any male whi says the swear word about the type of politics.

Mother-In-Law in the type of swear word show that eight male and two female use this word.

\section{Sample 10}

\section{Female user}

Devina: anoh jiah guru aneh during the observation, based on the results found men never use converstions that lead to type mother-in-law.

The animals as type of swear word there is fourteen male and eight female who say this word.

\section{Sample 11}

\section{Male user}

Soleh: patek jeh neng neng deiyyeh

Fery: patek

\section{Sample 12}

\section{Female user}

\section{Devina: iyeh, patek}

Nickname is a type of swear word spoken by twelve male students and ten female students.

\section{Sample 13}

\section{Male user}

Irfan: coonnggg hahahahahaha

\section{Sample 14}

\section{Female user}

Devina: kamaa'ah kakeh coonngg mek lakoh entar kannak. A sekolah kannak enjek. Coonnggg coonngg

As for the rude commentwhich is the last type of swear word showing different results in questionnaires distribution, there are four male students and nine female students. In this type more women use the form of rude comment because they are more aggressive than men. The results show that men are more dominant in the use of swear words compared to women.

\section{Sample 15}

\section{Male user}

Mosleh: enjek apah nyenget enjek

Sample 16

\section{Female user}

Devina: se tampangah nyenget joh se peng cemprengan suaranah joh

The researchers analyzed the results of the recording data and field notes which show that there is an oath in the same type used by students based on gender. Data is taken based on students' conversations within the scope of class XI IPS3 students. Based on the type of oath above, it is explained that there are several types of words that are not said during the data collection process. But the results of the questionnaire distributed and filled out based on students' experience in the use of swear words have been classified as gender based as explained above.

Overall, most types of swear words used by students by sex in class XI IPS 3, SMAN 4 Bangkalan show that men use swear words more than their experience. Guvendir (2015) considers that men are stronger than women when using the word oath. Furthermore, women are considered to be more aggressive and talkative especially in the use and behavior of swear words spoken by high school students. Based on research results, the form of the word oath in women's pronunciation is more dominant because the word oath is often repeated in their conversations. Women use more words 
when they are in the group themselves, while men have the potential to use the word oath wherever they are because they are braver. Women also often use pragmatics in their conversations, in contrast to men who are more to the point. Curse words used by students are the insertion of words from sentences that have different meanings in their use. This is related to the statement of Holmes (2008) that women are identical with feminine and masculine men. This shows that women are gentle and can maintain their attitude when talking to others. The type of swear words applied by students in their conversations are used to convey selfexpression to each other so that they have certain forms and functions in their use.

\section{CONCLUSION}

In conclusion, the researchers can conclude that there are eleven types of swear words used by students based on the gender 'male' and female. This includes, sex, death, excretion, bodily functions, religious matters, politics, motherin-law, animals, left hand, nickname, and rude comment. In the eleven types of swear words, students never use the word swear 'left hand' because this research focuses on students' words and expressions. The form of an oath used by students consists of many types of pronunciations. Words and expressions make the difference between male and female pronunciation. There are forty-two forms of swear words that are used by students who are put into their communication to interact within the scope of the school.

\section{REFERENCES}

Afifi, M. (2007). Gender Differences in Mental Health. GoogleSchoolar, 7.

Aji, B. P. (2014). The Use of Swear Words in "Four Brothers" Movie. Surabaya: Faculty of Letters and Humanities State Islamic University UIN Sunan Ampel.

Ary, D. (2010). Introduction to Research in Education. Canada: Wadsworth.

Creswell, J. W. (2012). Educational Research Planning, Conducting and Evaluating Quantitative and Qualitative Research.United States of America: Library of Congress Cataloging.

Flick, U. (2009). An Introduction to Qualitative Research Fourth Edition Sage. London: Sage.

Google: https://liberalarts.utexas.edu Meyerhoff, M. (2006). Introducing Sociolinguistics. New York: Routledge.

Guvendir, E. (2015). Why Are Males Inclined to Use Strong Swear Words More than Females? An Evolutionary Explanation Based on Male Intergroup Aggressiveness. ScienceDirect, 7.

Holmes, J. (2008). An Introduction to Sociolinguistics. England: Sustainable Forests.

Jay, T. (2009). The Utility and Ubiquity of Taboo Words. SAGE Journals, 9.

Jendra, I. I. (2010). Sociolinguistics the Study of Societies Languages. Yogyakarta: Graha Ilmu.

Masaki, Y. (2004, 12 13). Critique of J. L. Austin Speech Act Theory. Retrieved from Google: www.caj1971.com

Nurhayati. (2007). the Use of Swear Words and its Relationship with Taboo Words in Crank. 122.

Popusoi, S. A. (2018). Get the F\#*k Out My Way! "Exploring the Carhartic Effect of Swear Words in Coping with Driving Anger. Elsevier, 12.

Putra, R. R. (2012). Bentuk dan Fungsi Kata Umpatan pada Komunikasi Informal di Kalangan Siswa SMA Negeri 3 Surabaya: Kajian Sosiolinguistik. Google scholar, 13.

Samara, A. (2017). Acquiring Variation in An Artificial Language: Children and Adults Are Sensitive to Socially Conditioned Linguistic Variation. Elsevier, 30.

Spolsky, B. (2003). Sociolinguistics. New York: Oxford University Press.

Sumarsono, M. E. (2012). Sosiolinguistik. Yogyakarta: SABDA.

Taguchi, N. (2018). Description and Explanation of Pragmatic Development: Quantitative, Qualitative, and Mixed Methods Research. Elsevier, 10.

Wahyuningsih, S. (2018). Men and Women Differences in Using Language: A Case Study of Students at STAIN Kudus. English Education, Literature, and Culture (EduLite), 12.

Wardhaugh, R. (2006). An Introduction to Sociolinguistics.Australia: Blackwell.

Yule, G. (2010). The Study of Language. New York: Cambridge University Press. 